\title{
Glutamate Responses of Bipolar Cells in a Slice Preparation of the Rat Retina
}

\author{
Thomas Euler, Horst Schneider, and Heinz Wässle \\ Max-Planck-Institut für Hirnforschung, Deutschordenstrasse 46, D-60528 Frankfurt, Germany
}

Whole-cell currents from $>70$ voltage-clamped bipolar cells were recorded in a slice preparation of the rat retina. The recorded cells were identified and classified by intracellular staining with Lucifer yellow. Glutamate, the specific agonists ( \pm )-2-amino-4-phosphonobutyric acid (AP-4) and kainate (KA), and the antagonist 6-cyanoquinoxaline-2,3-dione (CNQX) were applied. The cells could be isolated from presynaptic influences by the co-application of bicuculline, strychnine, and cobalt ions. Responses to AP-4 were elicited only from bipolar cells with axons stratifying in the inner part of the inner plexiform layer (IPL). AP-4 caused an outward current in these cells attributable to the closure of nonspecific cation channels. Responses to kainate representing a direct action of the drug on the recorded cells were observed only in bipolar cells with axons stratifying in the outer part of the IPL. KA caused a CNQX-sensitive inward current in these cells, associated with openings of nonspecific cation channels. The results predict that cone bipolar $(\mathrm{CB})$ cells with axons terminating in the outer IPL are OFF-bipolars, whereas those with axons terminating in the inner IPL are ON-bipolars. Most of the cells expressed GABA-gated $\mathrm{Cl}^{-}$conductances. In rod bipolar and in some $\mathrm{CB}$ cells, only part of the GABA-induced currents could be blocked by the application of bicuculline, suggesting the presence of $\mathrm{GABA}_{\mathrm{C}}$ receptors in addition to $\mathrm{GABA}_{\mathrm{A}}$ receptors.

Key words: retina; slice; whole-cell currents; cone bipolar cells; rod bipolar cells; ON-cells; OFF-cells; AP-4 receptor; glutamate receptor; $G A B A_{C}$ receptor
Bipolar cells of the mammalian retina can be subdivided, according to their morphology, into many different types. Ramón y Cajal (1893) recognized rod bipolar (RB) cells as a separate class. Their dendrites make invaginating contacts with rod spherules, and their axons terminate in the innermost part of the inner plexiform layer (IPL) (Kolb, 1970; Boycott and Kolb, 1973; Dacheux and Raviola, 1986; Greferath et al., 1990). There are approximately 10 types of cone bipolar (CB) cells in the mammalian retina (cat: Famiglietti, 1981; Kolb et al., 1981; McGuire et al., 1984; Pourcho and Goebel, 1987; Cohen and Sterling, 1990 a,b; rabbit: Famiglietti, 1981; Mills and Massey, 1992; Jeon and Masland, 1995; monkey: Boycott and Wässle, 1991; rat: Euler and Wässle, 1995a). They differ in the branching pattern of their dendrites, the number of cones contacted, and the shape and stratification of their axons in the IPL.

In contrast to the wealth of morphological and immunocytochemical data, only limited and sometimes conflicting information is available concerning the physiological responses of bipolar cells in the mammalian retina. Intracellular recordings from RB cells of the cat retina suggest that they give OFF-center responses (Nelson et al., 1976), whereas ON-center responses were found in rabbits (Dacheux and Raviola, 1986). Intracellular recordings have been made from three types of CB cells of the cat retina: $c b 2$, cb5, and cb6 (Nelson and Kolb, 1983). Cell cb2 was an OFFcenter cell, and cell cb5 was an ON-center cell. Their axons terminated in the outer and inner half of the IPL, respectively. Cell type cb6 did not follow the rule; it was an OFF-center cell, but its axon terminated in the inner half of the IPL.

Received Jan. 16, 1996; accepted Feb. 9, 1996.

We thank F. Boij for technical assistance and I. Odenthal for typing the manuscript. We are grateful to Dr. B. B. Boycott and Dr. Rowland Taylor for helpful discussions.

Correspondence should be addressed to Heinz Wässle, Max-Planck-Institut für Hirnforschung, Deutschordenstrasse 46, D-60528 Frankfurt, Germany.

Copyright (C) 1996 Society for Neuroscience $0270-6474 / 96 / 162934-11 \$ 05.00 / 0$
Dissociated RB cells of rat and cat retinae have a ( \pm )-2-amino4-phosphonobutyric acid (AP-4)-type glutamate (GLU) receptor (GluR) and therefore are ON-center bipolar cells (Yamashita and Wässle, 1991b; de la Villa et al., 1995). Dissociated CB cells of the cat retina display either AP-4-type GluRs or conventional ionotropic receptors (de la Villa et al., 1995). Unfortunately, it was not possible to define the morphological types of these dissociated CB cells.

Recently the retinal slice technique (Werblin, 1978; Wu, 1987) was developed for the mammalian retina (Edwards et al., 1989; Boos et al., 1993), allowing patch-clamp recording of voltage- and transmitter-gated currents of retinal neurons. In the present study, we applied this method to study the different types of bipolar cell of the rat retina. The patch-clamp electrodes were filled with Lucifer yellow (LY), which diffused into the bipolar cells during the recordings, and it was possible to classify them according to the scheme we proposed recently (Euler and Wässle, 1995a). The responses of the cells to the application of GLU and its different analogs or antagonists were measured. In this way, it was possible to decide whether the cells expressed an AP-4-type of GluR or a kainate (KA)/AMPA type, and to predict whether they were putative ON- or OFF-bipolar cells, respectively.

$\Lambda$ preliminary report of this work has been given previously in abstract form (Euler and Wässle, 1995b).

\section{MATERIALS AND METHODS}

Tissue preparation. Adult albino rats (lab strain) were anesthetized deeply with halothane and decapitated. The eyes were removed quickly and transferred to a plastic Petri dish containing ice-cold HEPES-buffered physiological saline [extracellular standard medium (ES); see Solutions and drug application ], which had been bubbled with oxygen for $0.5 \mathrm{hr}$. The eye was opened by an encircling cut along the ora serrata, and the vitreous was dissected out. The retina was removed carefully from the sclera and cut into quarters. One of the quarters was held with a pair of forceps, and thin slices of $100-200 \mu \mathrm{m}$ were cut by "rolling" the curved edge of a 
scalpel blade through the piece (Boos et al., 1993). Approximately eight slices were transferred into a recording chamber and placed with the cut side up. The slices were held in place by a grid of parallel nylon strings (Edwards et al., 1989). The remaining three quarters of retina could be well maintained for up to $8 \mathrm{hr}$ in oxygenated $\mathrm{ES}$ at room temperature $\left(\sim 20^{\circ} \mathrm{C}\right)$.

The retina became completely blcached by the microscope lamps during the dissection and in the course of the experiments, and therefore light responses were observed only in some rare cases. Although the slicing undoubtedly damaged many cells near the surface of the slices, we routinely observed synaptic potentials, which could be blocked by $\mathrm{Co}^{2+}$, indicating that the connectivity of the retina was intact.

Recording chamber and optical setup. The recording chamber was placed on the fixed stage of a microscope (Zeiss ACM). The microscope was equipped with epifluorescence illumination and differential interference contrast (Nomarski) optics. The bare metal of the water immersion objective (Zeiss, $40 / 0.75 \mathrm{~W}$ ) was insulated to prevent electrical contact with the bath solution. The recording chamber was perfused continuously (2-3 $\mathrm{ml} / \mathrm{min}$ ) with oxygenated ES. A valve on the inflow allowed the recording chamber to be perfused with different extracellular solutions. The extracellular solution was exchanged completely within $\sim 2 \mathrm{~min}$.

Patch electrodes were pulled from borosilicate glass (outer diameter $1.5 \mathrm{~mm}$, wall thickness $0.3 \mathrm{~mm}$; Clark, Redding, UK) on a horizontal electrode puller (DMZ-Universal Puller, Zeitz Instrumente, Augsburg, Germany). The electrodes were heat-polished, and their resistance when filled with intracellular solution was $6-15 \mathrm{M} \Omega$.

Whole-cell and perforated-patch recordings. Both conventional wholecell recordings (Hamill et al., 1981) and perforated-patch techniques (Horn and Marty, 1988) were used. For both configurations, we routinely added the antibiotic Nystatin (Sigma Aldrich, Deisenhofen, Germany) to the intracellular solutions at different concentrations. In the conventional mode, it often was difficult to break into the small somata of the bipolar cells. With a low concentration of Nystatin $(20-50 \mu \mathrm{g} / \mathrm{ml})$ in the patch electrode, it was much easier to rupture the membrane without damaging the seal. Although Nystatin entered the cell as a consequence of this procedure, we did not observe differences when compared with normal whole-cell recordings without Nystatin. Therefore the effects of low concentrations of intracellular Nystatin are probably negligible. Because LY (potassium salt, Sigma Aldrich) was included in the intracellular solution $(250 \mu \mathrm{g} / \mathrm{ml})$, the cell filled rapidly after the whole-cell configuration was established. Within $<1$ min, fine processes were well filled.

In the perforated-patch method, we added Nystatin at a final concentration of $300 \mu \mathrm{g} / \mathrm{ml}$. As described in detail by IIorn and Marty (1988) and Yamashita and Wässle (1991a,b), the membrane under the electrode became electrically permeable within $-2 \mathrm{~min}$ after the seal formation. No filling of the cells with LY was observed, indicating that the patch was intact. At the end of the recordings, the patch was ruptured to fill the cells with LY, and their morphology became visible under the fluorescent light.

All recordings were made with an EPC-7 patch-clamp amplifier (List, Darmstadt, Germany). The recording electrode was connected via an $\mathrm{Ag}$ / $\mathrm{AgCl}$ wire to the preamplifier; the reference electrode was an $\mathrm{Ag} / \mathrm{AgCl}$ pellet in contact with the bath solution. Capacitative currents caused by the electrodes were canceled by the circuit of the EPC-7 amplifier. Additional capacitativc currents, which reficcted the capacitance of the cell membrane, appeared within a few minutes after sealing onto the cell in perforated-patch mode or immediately after breaking into the cell.

Series resistances were estimated from the peak amplitudes of the capacitative currents. Because the peak amplitudes of the capacitive currents were attenuated by the limited sampling frequency of the recording system, the series resistances are overestimated. In the whole-cell mode, they ranged from 20 to $70 \mathrm{M} \Omega$. In the perforated-patch configuration, series resistance can be relatively high and was estimated to range from 45 to $100 \mathrm{M} \Omega$. In general, the bipolar cells were voltage-clamped within the range of -80 to $+20 \mathrm{mV}$. Within that voltage range, both leakage and voltage-activated currents were relatively small. Much of the data presented in the following are qualitative in nature, and therefore series-resistance errors are not important. For the measurements in which series-resistance errors could cause problems, i.e., reversal potential measurements, $\mathrm{Cs}^{+}$instead of $\mathrm{K}^{+}$was used as the internal cation.

Liquid junction potentials of the patch electrode were measured as described by Fenwick et al. (1982) and also were calculated using the DUS software JPCALC by Barry (1994). Measurements and calculations showed good agreement. Because of the sensitivity of the system for different chloride concentrations in the intracellular medium, the liquid junction potentials for different combinations of solutions ranged from $3.7 \mathrm{mV}$ (for symmetric concentrations of chloride) to $15.2 \mathrm{mV}$ (with low intracellulary chloride concentration). Because most of our results are concerned with a comparison of ligand-gated currents, these possible errors do not influence the results, except for the accuracy of the absolute value of the reversal potentials. We addressed this problem by correcting all holding potentials for the appropriate liquid junction potentials independent from the recording mode. The extrapolated reversal potentials for both recording configurations are similar to those found by others under comparable conditions (Karschin and Wässle, 1990; Yamashita and Wässle, 1991 a,b; de la Villa et al., 1995), suggesting that the errors are rather small.

Signals were low-pass filtered (Bessel) at $40 \mathrm{~Hz}$ (AP-255-5, A.P. Circuit) and digitized at $200 \mathrm{~Hz}$ using the PCLAMP 6.02 software (Axon Instruments) in conjunction with a Labmaster AD/DA board. Additional data analysis was conducted with ORIGIN for Windows (version 3.73, Microcal Software).

Solutions and drug application. The standard ES, which was used for the preparation and during the experiment, contained (in mM): $137 \mathrm{NaCl}, 5 \mathrm{KCl}$, $2 \mathrm{CaCl}_{2}, 1 \mathrm{Na}_{2} \mathrm{HPO}_{4}, 1 \mathrm{MgSO}_{4}, 10$ HEPES, and 22 glucose. To suppress synaptic transmission within the slice, a second type of $\mathrm{ES}$, which contained cobalt instead of calcium ions (ECO), was used (in mM): $137 \mathrm{NaCl}, 1 \mathrm{KCl}, 1$ $\mathrm{MgCl}_{2}, 10$ HEPES, 22 glucose, $3 \mathrm{CoCl}_{2}$, and 1 potassium-gluconate. The $\mathrm{pH}$ in both solutions was adjusted to 7.4. In some experiments, $100 \mu \mathrm{M}$ bicuculline (BIC) and $1 \mu \mathrm{M}$ strychnine (STRY) were added to ECO to exclude the possibility of cobalt-insensitive presyniaptic effects.

Three different types of intracellular solution were used. The first solution (I1) had the same concentration of chloride as the ES (symmetric chloride), and the other two intracellular solutions (12, 13) were prepared with a low, more physiological chloride concentration. Solution I1 contained (in mM): $10 \mathrm{NaCl}, 1 \mathrm{CaCl}_{2}, 2 \mathrm{MgCl}_{2}, 1.1$ EGTA, $2 \mathrm{Na}_{2}$-ATP, $10 \mathrm{HEPES}$, and $130 \mathrm{KCl}$. Solution I2 contained (in $\mathrm{mm}$ ): $10 \mathrm{NaCl}, 1$ $\mathrm{CaCl}_{2}, 2 \mathrm{MgCl}_{2}, 1.1 \mathrm{EGTA}, 2 \mathrm{Na}_{2}$-ATP, $10 \mathrm{HEPES}, 4 \mathrm{CsCl}$, and 126 cesium-gluconate. Solution 13 contained (in $\mathrm{mM}$ ): $10 \mathrm{NaCl}, 1 \mathrm{CaCl}_{2}, 2$ $\mathrm{MgCl}_{2}, 1.1 \mathrm{EGTA}, 2 \mathrm{Na}_{2}$-ATP, $10 \mathrm{HEPES}, 4 \mathrm{KCl}$, and 126 potassiumgluconate. The $\mathrm{pH}$ was adjusted to 7.2 .

Amplitudes of $\mathrm{AP}-4-, \mathrm{K} \Lambda_{-}^{-}$, or $\mathrm{G} \wedge \mathrm{B} \Lambda$-induced currents given in Results always were measured at the resting potential of the cells with a low, more physiological internal $\mathrm{Cl}^{-}$concentration (Yamashita and Wässle, 1991a). LY and Nystatin (see above) were added to all intracellular solutions. Nystatin was prepared freshly in dimethyl sulfoxide $(100 \mathrm{mg} / \mathrm{ml}$, Sigma Aldrich) and then sonicated for 5 min before use.

Because the pressure application system has been described in detail elsewhere (Boos et al., 1993), we will give only a short description here. The drug solutions were prepared from frozen aliquots of stock solution, dissolved in ES, and applied from seven-barreled pneumatic puffer pipettes. These puffer pipettes, with tip diameters of $\sim 15 \mu \mathrm{m}$, were placed within $-30 \mu \mathrm{m}$ of the recorded cell. Drug solutions were ejected by applying $0.3-0.5$ bar of air pressure. Without pressure applied to the pipette, small amounts of bath solution flowed continuously into the tip of the pipcttc by capillary attraction and hence prevented the drug solutions from leaking out.

Agonists and antagonists of GLU and GABA receptors were applied. The concentration of the drugs quoted (given in parentheses) refers to the concentrations in the barrel of the puffer pipette. These were relatively high; however, the actual concentration at the cell membrane undoubtedly was lower. The concentrations were chosen on the basis of our previous experiments on dissociated RB cells (Karschin and Wässle, 1990; Yamashita and Wässle, 1991a,b) and on rat retinal slices (Boos et al., 1993) in which the same perfusion system and the same application system were used. GLU (200 $\mu \mathrm{M}-1 \mathrm{~mm}), \mathrm{GABA}(25 \mu \mathrm{M})$, and AP-4 (300 $\mu \mathrm{M})$ were obtained from Sigma Aldrich. KA $(200-500 \mu \mathrm{M})$, L-transpyrrolidine-2,4-dicarboxylic acid (L-tPDC, $250 \mu \mathrm{M}$ ), and the putative mGluR5 agonist ( \pm )-trans-azetidine-2,4-dicarboxylic acid (tADA, $1 \mathrm{~mm}$ ) were obtained from Tocris (Bristol, UK). The KA/AMPA-rcceptor antagonist CNQX $(25 \mu \mathrm{M}), \mathrm{BIC}(100 \mu \mathrm{M})$, and the $\mathrm{GABA}_{\mathrm{B}}$-receptor agonist baclofen (BAC, $500 \mu \mathrm{M}$ ) were obtained from RBI (Natick, MA). STRY $(1 \mu \mathrm{M})$ was provided by SERVA (Heidelberg, Germany). Sodium-ATP, $\mathrm{CsOH}$, gluconic acid, and HEPES were obtained from Sigma Aldrich. All other chemicals were provided by Merck (Darmstadt, Germany).

\section{RESULTS}

\section{Identification and classification of bipolar cells}

By using Nomarski optics, individual neurons within the different layers of the retinal slice can be recognized (Fig. $1 A$ ). RB cell bodies are found more often in the outermost part of the INL, cell bodies 

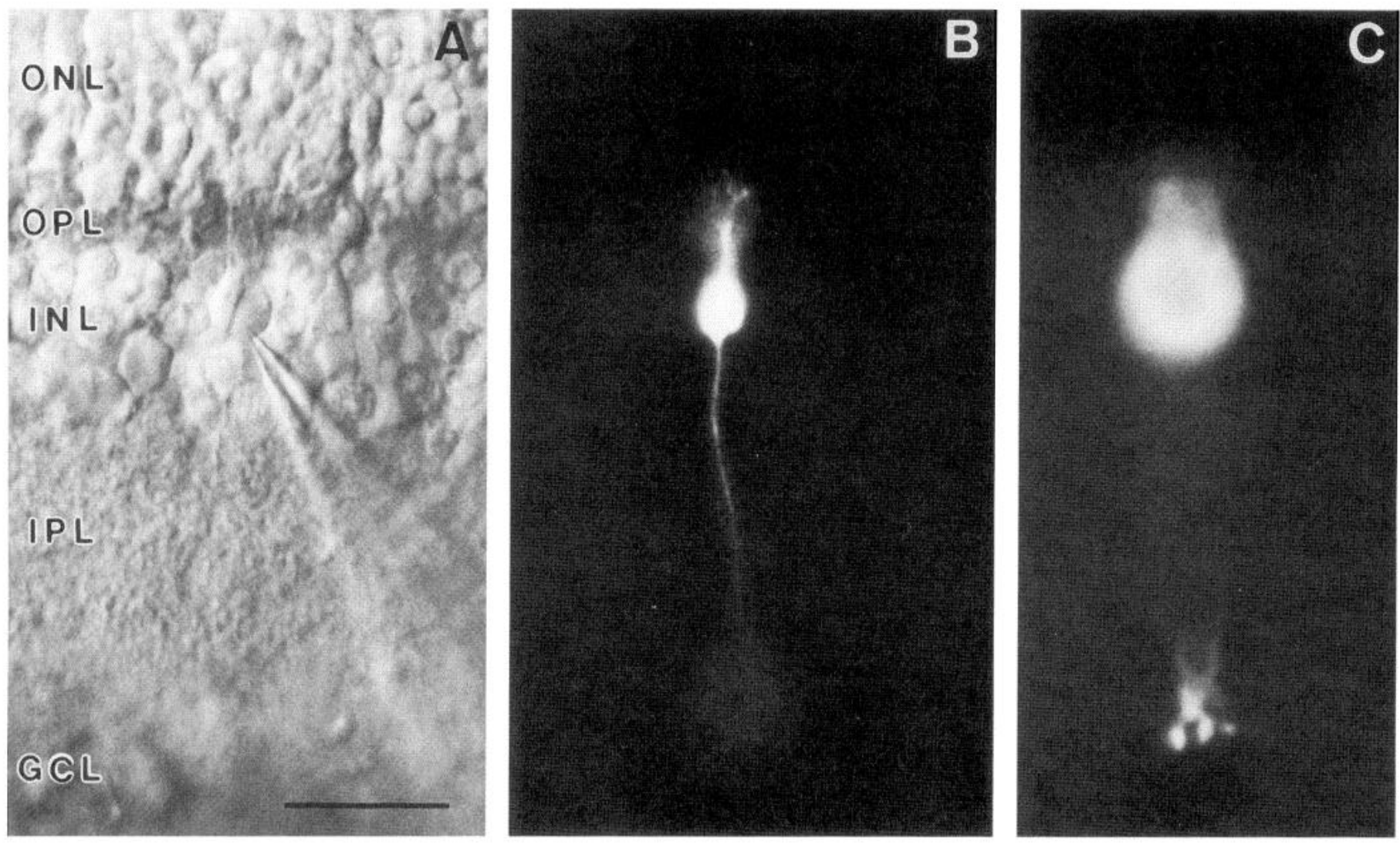

D

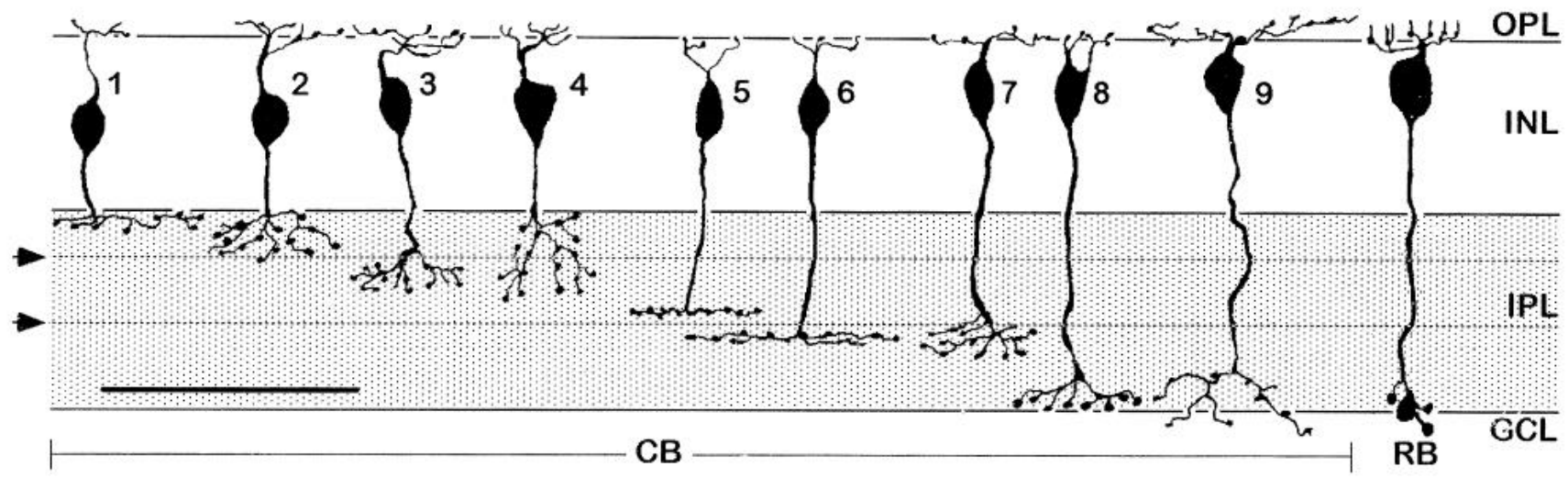

Figure 1. Slice preparation of a rat retina during a patch-clamp recording from an RB cell. $A$, In this Nomarski micrograph, the retinal layers are indicated $(O N L$, outer nuclear layer; $O P L$, outer plexiform layer; $I N L$, inner nuclear layer; $I P L$, inner plexiform layer; $G C L$, ganglion cell layer). The patch electrode, of which only the tip is in focus, sits on the soma of a bipolar cell. The puffer pipette for drug application is not visible (scale bar, $25 \mu \mathrm{m}$ ). $B$ and $C$, Fluorescence micrographs of the recorded bipolar cell, filled with LY. The dendrites and the soma are in focus in $B$; the axon terminal is in focus in $C . D$, Summary diagram of the types of bipolar cell described by Euler and Wässle (1995a). The nine different putative CB cells stratify at different levels within the IPL and are arrayed accordingly. An RB cell is shown to the right. The two horizontal lines subdividing the IPL (arrowheads) represent the stratification level of OFF (outer) and ON (inner) cholinergic amacrine cells (scale bar, $60 \mu \mathrm{m}$ ).

(CBs) more toward the center. Hence, to some extent it was possible to select RBs or CBs according to their cell body position. We filled the cells with LY during the recordings and thus were able to verify their identity according to the classification scheme proposed by Euler and Wässle (1995a) and summarized in Fig. 1D. The CB cells are arranged according to the stratification level of their axonsfrom outer to inner-and are numbered accordingly. Figure $1 \mathrm{~A}$ shows the slice and the recording pipette contacting an RB cell body.
The same bipolar cell using fluorescence illumination is shown in Fig. $1 B, C$. Its axon terminates close to the ganglion cell layer and has varicosities, which are the features of RB cells (Fig. $1 D, R B$ ).

Altogether we recorded 78 bipolar cells in the present study; of these, 59 could be classified according to the scheme in Fig. $1 D$. The remaining cells were filled only partially. The resting potentials of RB $(-45 \pm 13 \mathrm{mV} ; n=21)$ and CB cells $(-49 \pm 10 \mathrm{mV}$; $n=38$ ) were in the broad range given in the literature for 
Table 1. Type and number of identified bipolar cells that responded to AP-4, KA, or GABA

$\mathrm{CB}$ cells

\begin{tabular}{|c|c|c|c|c|c|c|c|c|c|c|}
\hline Type & 1 & 2 & 3 & 4 & 5 & 6 & 7 & 8 & 9 & \\
\hline$(n)$ & $(1)$ & (2) & (3) & (4) & (5) & (8) & (6) & $(5)$ & $(0)$ & (23) \\
\hline $\mathrm{AP}-4$ & $0 / 1$ & $0 / 2$ & $0 / 3$ & $0 / 4$ & $1 / 5$ & $7 / 8$ & $3 / 4$ & $2 / 2$ & 0 & $11 / 22$ \\
\hline KA direct & $1 / 1$ & $2 / 2$ & $3 / 3$ & $3 / 3$ & $4 / 5$ & $0 / 7$ & $1 / 4$ & $0 / 4$ & 0 & $2 / 21$ \\
\hline KA presynaptic & $0 / 1$ & $0 / 2$ & $0 / 3$ & $0 / 3$ & $0 / 5$ & $4 / 7$ & $2 / 4$ & $4 / 4$ & 0 & $7 / 21$ \\
\hline \multirow[t]{2}{*}{ GABA } & $1 / 1$ & $1 / 2$ & $3 / 3$ & $3 / 3$ & $4 / 5$ & $6 / 8$ & $4 / 4$ & $4 / 4$ & 0 & $18 / 19$ \\
\hline & \multicolumn{5}{|c|}{ OFF } & \multicolumn{5}{|c|}{ ON } \\
\hline
\end{tabular}

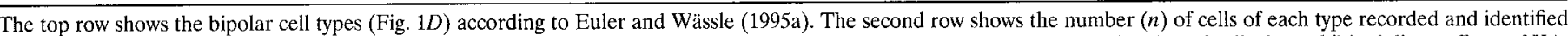

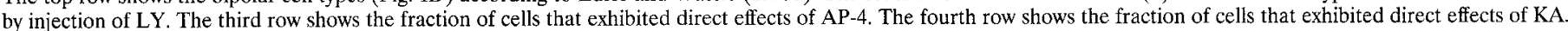

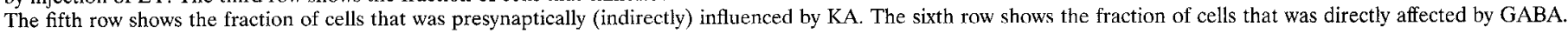
The bottom row shows putative OFF and ON cells.
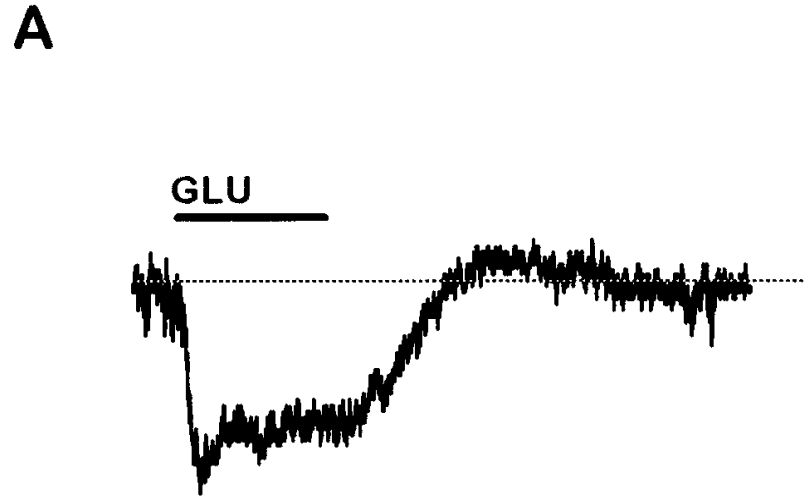

$V_{C}=-55 \mathrm{mV}$
B

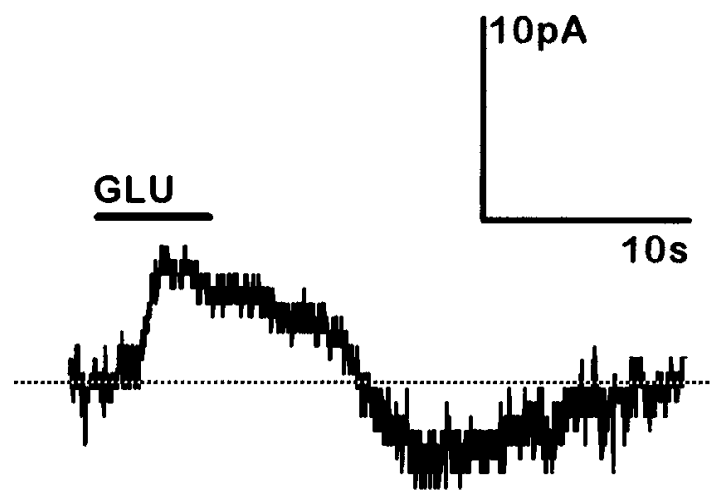

$V_{c}=-48 m V$

Figure 2. A, GLU-activated whole-cell currents from a bipolar cell voltage clamped at $-55 \mathrm{mV}$. The cell was identified as a type $5 \mathrm{CB}$ cell. Application of GLU (horizontal bar) activated first an inward current, followed by an outward current. $B$, GLU applied to an RB cell clamped at $-48 \mathrm{mV}$ first activated an outward current, followed by an inward current. The dotted line represents the steady-state current (intracellular solution, I3; extracellular solution, ES; conventional whole-cell recording).

dissociated RB cells (Karschin and Wässle, 1990; Suzuki et al., 1990; Yeh et al., 1990; Yamashita and Wässle, 1991b). No significant differences were observed between RB cells or different CB cells. Twenty-three RB and $34 \mathrm{CB}$ cells could be analyzed in detail, and their relative numbers are indicated in Table 1. The type 9 CB cell, which is a putative blue CB cell (Euler and Wässle, 1995a), was not encountered.

All cells showed GLU-induced whole-cell currents. The cells could be divided into two major groups (Fig. $2 A, B$ ): bipolar cells in which GLU elicited inward currents (Fig. $2 A$ ) and bipolar cells in which GLU elicited outward currents (Fig. $2 B$ ). In many instances, however, these currents were biphasic, suggesting direct and indirect actions of GLU on the recorded cells. It was not possible here to perform a detailed pharmacological analysis of the GluRs expressed by the different types of bipolar cells. Recordings of these extremely small cells in a slice are difficult, the time course of the drug application system is relatively slow, and the exact concentration of the drugs at the cell membrane is unknown. Our major aim is to show which cells are putative ON- and which are OFF-bipolar cells.

\section{Responses of bipolar cells to different GLU agonists}

Four possible direct actions of GLU and related agonists on bipolar cells are known from nonmammalian retinae (for review, see Shiells, 1995). (1) GLU can open nonspecific cation channels of the KA/AMPA type, which is the action found in OFF-bipolar cells (Attwell et al., 1987; Hensley et al., 1993; Kim and Miller, 1993). (2) GLU can close nonspecific cation channels by binding to a metabotropic (AP-4-type) receptor, which was described for ON-bipolar cells (Nawy and Jahr, 1990, 1991; Shiells and Falk, 1990, 1992 a,b). (3) GLU can open specific channels (such as $\mathrm{K}^{+}$ channels), as has been described for some fish and tiger salamander ON-bipolar cells (Saito et al., 1979, 1981; Nawy and Copenhagen, 1987, 1990; Hirano and MacLeish, 1991). (4) GLU can activate a chloride channel by a receptor with GLUtransporter-like pharmacology (Grant and Dowling, 1995).

In addition to the direct action of GLU, indirect actions are produced when GLU acts on neurons presynaptic to the bipolar cells. Such indirect actions might involve activation of amacrinc cells, horizontal cells, and photoreceptors. ECO was used to block $\mathrm{Ca}^{2+}$-dependent transmitter release from photoreceptors and amacrine cells. Transmitter release from horizontal cells is more problematic because it has been shown in nonmammalian retinae to be $\mathrm{Ca}^{2+}$-independent (Schwartz, 1982) and thus might not be blocked by $\mathrm{Co}^{2+}$ ions. Therefore, BIC and STRY were included in the bathing solution to block GABAergic input from horizontal and amacrine cells and also glycinergic input from amacrine cells; however, the recent discovery of BIC and picrotoxin-insensitive $\mathrm{GABA}_{\mathrm{C}}$-like responses in mammalian $\mathrm{RB}$ cells (Feigenspan et al., 


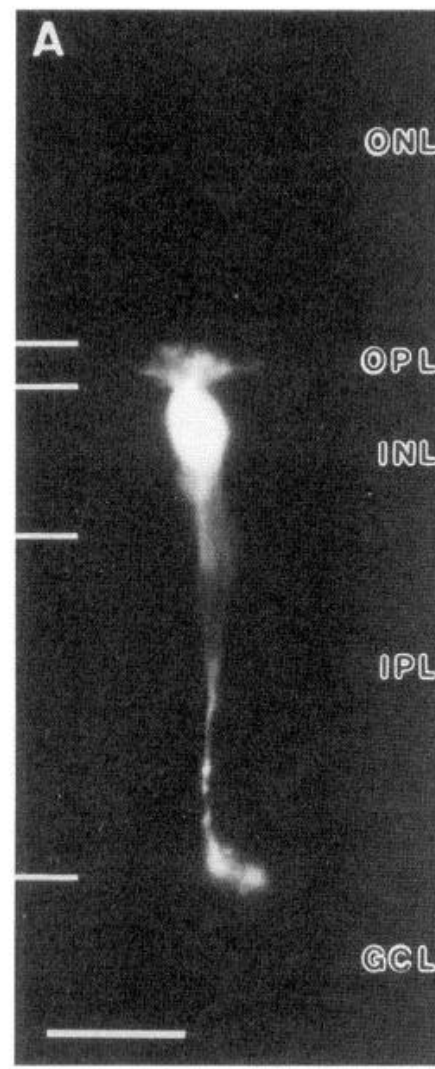

B

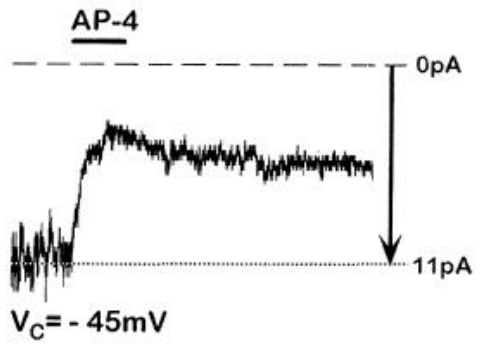

D

Figure 3. Whole-cell currents recorded from an identified RB cell in response to the application of GABA and GLU agonists and antagonists. A, Fluorescence micrograph of the recorded RB cell (scale bar, $20 \mu \mathrm{m}$ ). $B$, At the holding potential of $\mathrm{V}_{\mathrm{C}}=-45 \mathrm{mV}$, the cell exhibited a sustained inward current of $\sim 11 \mathrm{pA}$ (dotted line, arrow). Application of AP-4 (horizontal bar) caused an outward current and a reduction of the membrane noise. The long duration of the AP-4 response is probably attributable to the relatively high concentration of AP-4 in the application system and the time it takes to wash out from the slice. $C$, GABA also evoked an outward current. $D$, Using the bathing medium with $\mathrm{Co}^{2+}$, the application of KA evoked an outward current, which could be suppressed by the co-application of KA and CNQX and also BIC/STRY (intracellular solution, I3; extracellular solutions, ES/ECO; Nystatin perforated-patch recording). Abbreviations defined in Figure 1 legend.

1993) creates an additional problem. Therefore, symmetrical (I1) and low $\mathrm{Cl}^{-}$concentrations (I2, I3) were applied to determine whether $\mathrm{GABA}_{\mathrm{C}}$ receptors were involved in the responses measured.

Perforated-patch whole-cell recordings from an RB cell are shown in Fig. 3. The cell, filled with LY after the recordings (Fig. $3 A$ ), had the characteristic shape of an RB cell (Fig. 1D). The electrode contained a low concentration of $\mathrm{Cl}^{-}$(I3). The cell was voltage-clamped to $\mathrm{V}_{\mathrm{C}}=-45 \mathrm{mV}$, and a steady inward current of $11 \mathrm{pA}$ was measured (Fig. 3B, arrow). Application of AP-4 evoked a net outward current and a reduction in membrane noise (Fig. $3 B$ ) in 11 of $23 \mathrm{RB}$ cells tested (Table 1). The maximum amplitudes of AP-4-induced outward currents were between 5 and 20 pA. This outward current did not change in these 11 cells when $\mathrm{Co}^{2+}$, BIC, or STRY were applied with the bathing solution (not shown). The current-voltage relation ( $I-V$ curve) was steeper in the absence of AP-4 than during the application of AP-4; hence AP- 4 caused a conductance decrease $(190 \pm 10 \mathrm{pS} ; n=4)$. The reversal potential was $-6 \pm 16 \mathrm{mV}(n=4)$ and was shifted to more negative values when a low concentration of external $\mathrm{Na}^{+}$ was puffed onto the cell. GABA responses were measured in 18 of 19 RB cells tested (Fig. 3C). Similar currents also have been found in dissociated RB cells of rat and cat retinae (Yamashita and Wässle, 1991a; de la Villa et al., 1995), and they quite likely represent direct actions of the drug on the cell.

The cell also responded weakly to the application of KA, with an outward current that persisted in the presence of external $\mathrm{Co}^{2+}$
(Fig. 3D). As shown in Fig. 3D, however, it was blocked by co-application of CNQX and KA, suggesting the involvement of KA/AMPA receptors. The response to KA could also be blocked by the co-application of KA and a mixture of BIC and STRY (Fig. $3 D$ ). Together these results suggest that the KA/AMPA receptors are not on the RB cell but on neurons presynaptic to RB cells, possibly horizontal cells, where release of GABA is not blocked by $\mathrm{Co}^{2+}$. Such presynaptic effects of KA were observed in 7 of $21 \mathrm{RB}$ cells tested and ranged in amplitude between 5 and $60 \mathrm{pA}$. The reversal potential agreed with the $\mathrm{Cl}^{-}$reversal potential.

Whole-cell recordings from a CB cell are shown in Fig. 4. The cell had an axon branching in the inner portion of the IPL, close to the ganglion cell layer (Fig. $4 A$ ), and was identified as a type 8 $\mathrm{CB}$ cell (Fig. 1D). Similar to the responses of the RBs in 13 of the 29 CB cells tested, AP-4 evoked net outward currents between 5 and $20 \mathrm{pA}$, always accompanied by a reduction in membrane noise (Fig. $4 B$ ). Twelve of the $13 \mathrm{CB}$ cells had axon terminals in the inner part of the IPL (Table 1). The currents were resistant to the application of BIC and STRY or to superfusion with $\mathrm{Co}^{2+}$ (data not shown) and quite likely represented a direct action of AP-4. The reversal potential of the AP-4-evoked current averaged - 13 $\pm 10 \mathrm{mV}(n=4)$. GABA induced an inward current at the holding potential $\left(\mathrm{V}_{\mathrm{C}}=-53 \mathrm{mV}\right)$ because of the symmetrical $\mathrm{Cl}^{-}$ concentration (I1) (Fig. 4C). KA also induced a strong inward current; however, because $\mathrm{Co}^{2+}$ nearly completely blocked this current, it was very likely mediated via activation of a presynaptic cell (Fig. 4D). CNQX blocked the KA responses. 


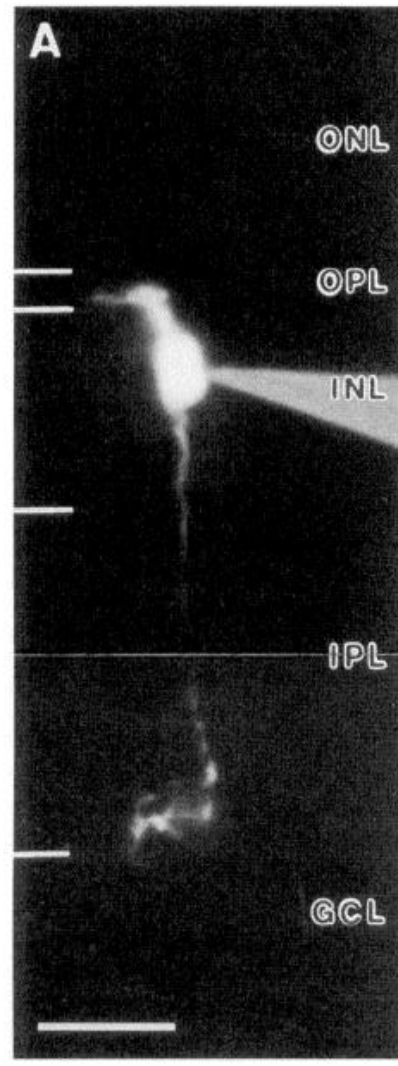

B

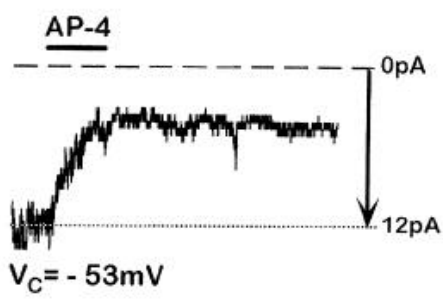

C

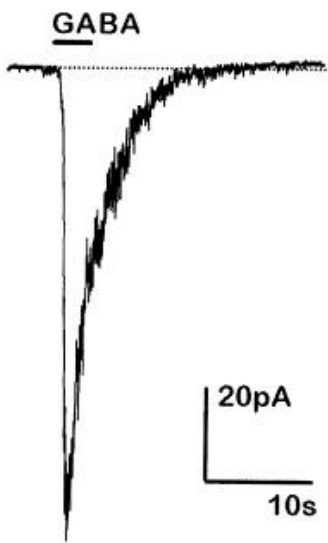

D

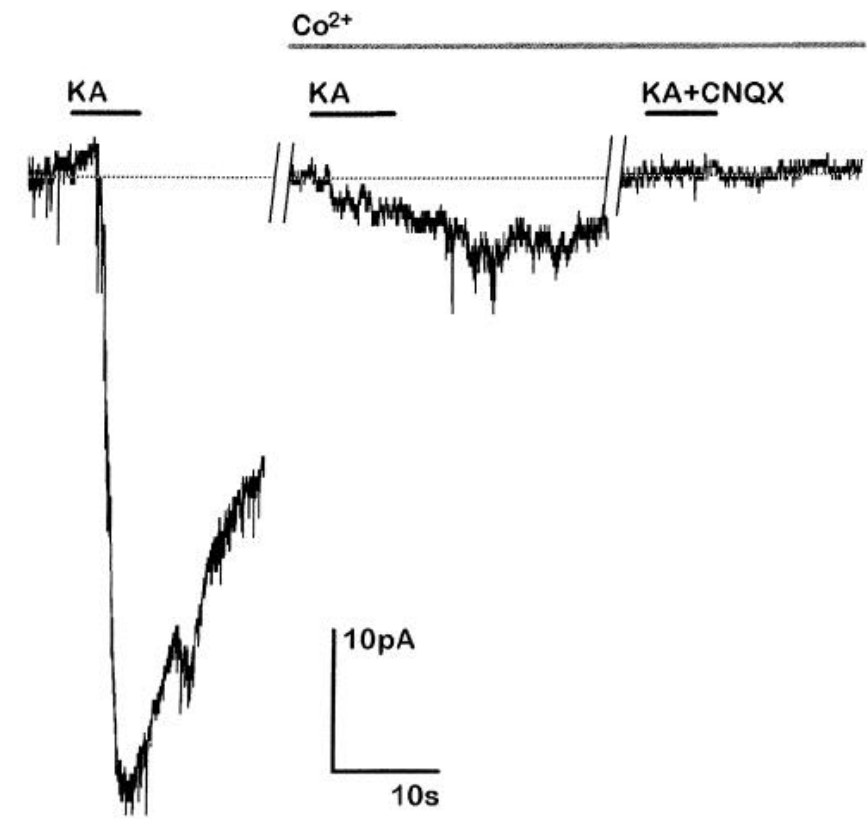

Figure 4. Whole-cell currents recorded from an identified type $8 \mathrm{CB}$ cell in response to the application of GABA and GLU agonists and antagonists. $A$, Fluorescence micrograph of the recorded type $8 \mathrm{CB}$ cell (scale bar, $20 \mu \mathrm{m}$ ). $B$, At the holding potential of $-53 \mathrm{mV}$, the cell exhibited a sustained inward current (dotted line, arrow); application of AP-4 caused an outward current and a reduction in membrane noise. $C$, Application of GABA induced a strong inward current. $D$, Application of KA induced a strong inward current, which was greatly reduced by $\mathrm{Co}^{2+}$ in the bathing medium and which was completely blocked when CNQX was co-applied (intracellular solution, I1; extracellular solutions, ES/ECO; conventional whole-cell recording). Abbreviations defined in Figure 1 legend.

Whole-cell recordings from a CB cell that behaved differently are shown in Fig. 5. The axon terminal of this cell was confined to the outer IPL, and the cell was classified as a type 2 CB cell (Figs. $5 A, 1 D)$. AP-4 did not elicit any current in this cell, but GLU evoked an inward current (Fig. $5 B$ ). KA evoked an even stronger inward current than GLU did, and this inward current was not significantly changed by using $\mathrm{Co}^{2+}$ containing bathing solution; however, it was abolished by CNQX (Fig. 5C). We interpret these findings as a direct action of GLU and KA on this CB cell. Such KA responses were observed in 14 of $29 \mathrm{CB}$ cells tested (Table 1). Thirteen of the CB cells showing direct KA responses had axon terminals in the outer part of the IPL. The maximum amplitude of KA-induced inward currents was between 40 and 120 pA. Reversal potentials were measured in $13 \mathrm{CB}$ cells; they shifted to more negative values when a low external $\mathrm{Na}^{+}$concentration was applied, and the average reversal potential was $-4 \pm 7 \mathrm{mV}$. In four of the outer stratifying bipolar cells, AP-4-induced currents could be observed; however, they were always indirect currents, which could be blocked by BIC and/or STRY.

In summary, there seems to be a clear dichotomy of bipolar cells with respect to their GluRs. Bipolar cells with axons terminating in the inner half of the IPL express AP-4 type receptors; bipolar cells with axon terminals in the outer half of the IPL express KA/AMPA type receptors (Table 1).

\section{GABA-induced currents of retinal bipolar cells}

RB cells dissociated from mammalian retinae show prominent GABA-gated $\mathrm{Cl}^{-}$conductances (mouse: Suzuki et al., 1990; rat:
Karschin and Wässle, 1990, Yeh et al., 1990; Yamashita and Wässle, 1991a,b; rabbit: Gillette and Dacheux, 1995). The $\mathrm{Cl}^{-}$ reversal potential is $\sim-70 \mathrm{mV}$ (Yamashita and Wässle, 1991a). The recent cloning of a retina-specific subunit of GABAreceptors, the $\rho$-subunit, (Polenzani et al., 1991), and the finding of GABA responses that are resistant to BIC (Feigenspan et al., 1993; Qian and Dowling, 1993), suggest that different types of GABA-gated $\mathrm{Cl}^{-}$channels might exist in bipolar cells.

GABA-activated $\mathrm{Cl}^{-}$currents recorded from amacrine cells in the organotypic slice culture and in the acute slice preparation could be blocked reliably by the co-application of $100 \mu \mathrm{M}$ BIC (Boos et al., 1993; Feigenspan et al., 1993). Similarly, glycineinduced currents were blocked by the application of $1 \mu \mathrm{M}$ STRY. The situation was different, however, for bipolar cells: a fraction of the GABA-activated current was resistant to BIC (Feigenspan et al., 1993).

Perforated-patch recordings from an RB cell with an electrode filled with a low $\mathrm{Cl}^{-}$concentration (I3) are shown in Fig. 6A. At very negative holding potentials, an inward current was elicited by $\mathrm{GABA}$, and at holding potentials more positive than $-70 \mathrm{mV}$, the current was outward. Co-application of BIC and STRY strongly reduced the GABA-activated current, but was not able to block it completely (Fig. 6B). The current-voltage relation is shown in Fig. $6 C$. Both the total (open circle) and the STRY/BIC-resistant (solid circle) GABA-induced currents have a reversal potential at -70 $\mathrm{mV}$, which corresponds to the $\mathrm{Cl}^{-}$reversal potential. Six of seven $\mathrm{RB}$ cells tested in this way showed such STRY/BIC-insensitive 


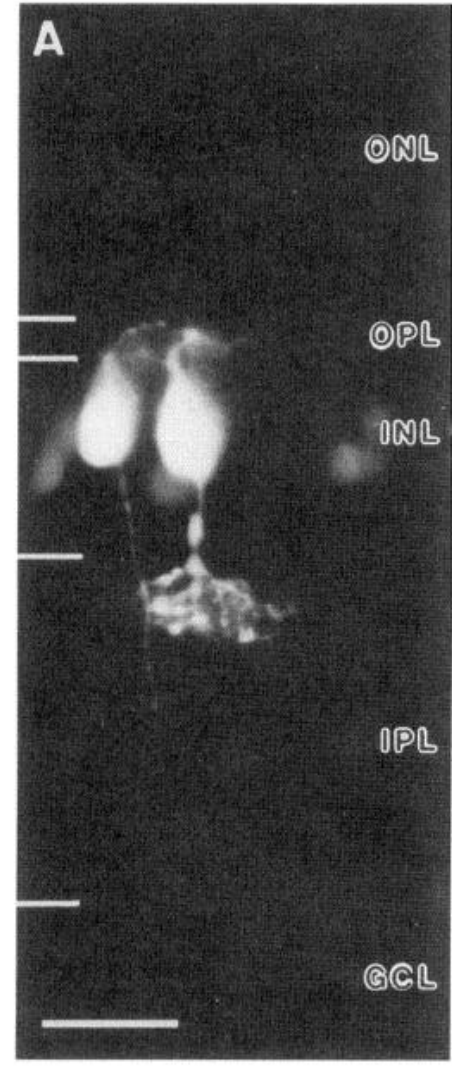

B

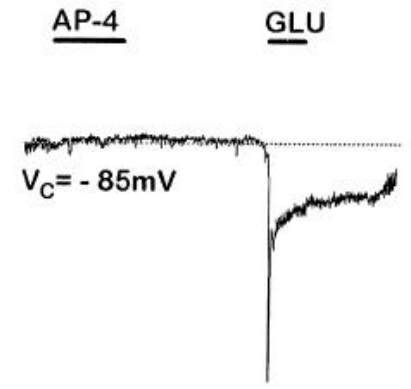

C

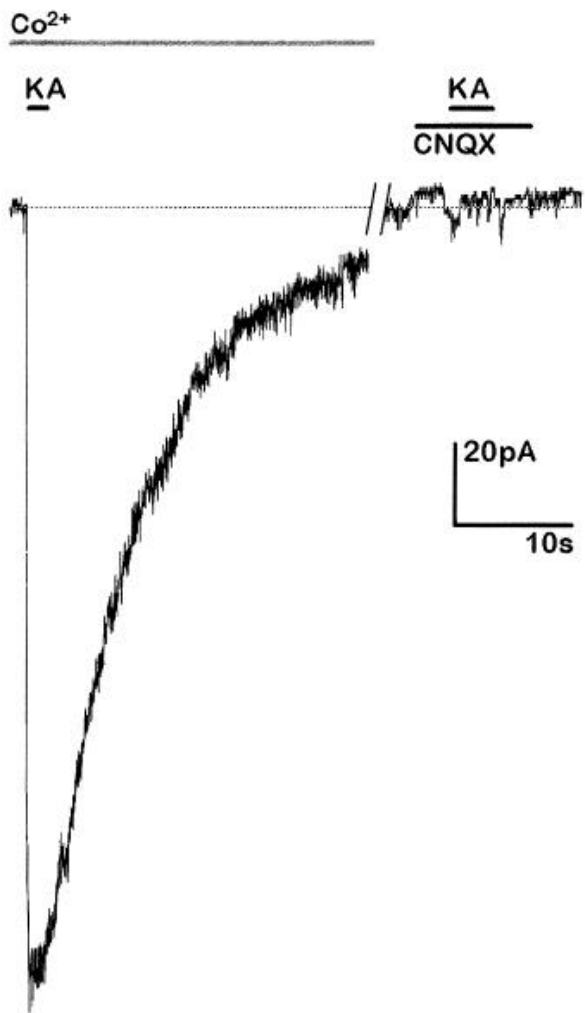

Figure 5. Whole-cell currents recorded from an identified type $2 \mathrm{CB}$ cell in response to the application of GLU, its agonists and antagonists. A, Fluorescence micrograph showing a type $2 \mathrm{CB}$ to the right. A second bipolar cell (left) was injected beforehand, but the axon terminal of this cell was chopped off when the slice was cut (scale bar, $20 \mu \mathrm{m}$ ). B, At a holding potential of $-85 \mathrm{mV}$, AP-4 and GLU were applied. The dotted line represents the steady-state current. AP-4 had no effect, and GLU induced an inward current with phasic and tonic components. $C$, KA induced a strong inward current, which could not be blocked by bath application of $\mathrm{Co}^{2+}$. This inward current was blocked by co-application of CNQX. The differences in amplitude and time course of GLU- and KA-induced currents might be attributable to differences in desensitization, as originally observed by Ishida and Neyton (1985) in isolated goldfish horizontal cells (extracellular solutions, ES/ECO; intracellular solution, I3; conventional whole-cell recording). Abbreviations defined in Figure 1 legend.

GABA-induced currents. The peak amplitudes of GABAactivated currents of $\mathrm{RB}$ cells clamped at the resting potential were between 10 and $80 \mathrm{pA}$. Application of STRY/BIC reduced the currents by $20-65 \%$. We also measured GABA-activated currents of $11 \mathrm{CB}$ cells. The current amplitudes were in the same range as those of RB cells. In four $\mathrm{CB}$ cells, GABA-activated currents were blocked effectively by STRY/BIC; in seven CB cells, they could not be blocked but were reduced by $50-80 \%$. We also applied $\mathrm{BAC}$, an agonist at $\mathrm{GABA}_{\mathrm{B}}$ receptors, to 18 bipolar cells. Of these, only four $\mathrm{CB}$ cells gave weak, noisy, and delayed responses.

\section{DISCUSSION}

Two morphological features of bipolar cells have been related to their physiological dichotomy into OFF- and ON-bipolar cells (for review, see Sterling et al., 1995). These are the type of synapses they make with photoreceptors, flat (OFF) or invaginating (ON) (Stell et al., 1977), and the level of stratification of their axons in the IPL, outer (OFF) or inner (ON) (Famiglietti and Kolb, 1976). There are, however, several examples of bipolar cells that do not follow this dichotomy of the cone contacts. Many OFF-bipolar cells make invaginating contacts, and ON-bipolar cells make flat contacts (for review, see Hopkins and Boycott, 1995; Kolb and Nelson, 1995). In addition, some bipolar cells make both flat and invaginating contacts with the same cone pedicle. It is therefore not possible to make a general prediction of the physiological type from the type of contact made at the cone. The stratification of the axon terminals in the IPL-outer representing OFF and inner representing $\mathrm{ON}$-seems to be true in most nonmammalian retinae (Famiglietti et al., 1977; Lasansky, 1978; Saito et al., 1983, 1985; Sakai and Naka, 1983; Werblin, 1991). In animals that have multistratified bipolar cell axons, however, this cannot be a strict rule (Ammermüller and Kolb, 1995).

\section{ON-bipolar cells of the rat retina}

$\mathrm{RB}$ and $\mathrm{CB}$ cells with axons terminating in the inner half of the IPL (CB types 6, 7, 8) express an AP-4 type GluR. In the absence of GLU, the channels are open and the cells are in a depolarized state. On binding of GLU, the channels close and the cells are hyperpolarized. Photoreceptors release GLU in darkness, and release is suppressed by light (Cervetto and MacNichol, 1972; Murakami et al., 1975; Marc and Lam, 1981; Ayoub et al., 1989; Copenhagen and Jahr, 1989). Consequently, the present findings suggest that RB cells and type 6, 7, and $8 \mathrm{CB}$ cells are depolarized by light and hyperpolarized in the dark and that they are ONbipolar cells.

The metabotropic GluR mGluR6 cloned from rat retina (Nakajima et al., 1993) was activated potently by AP-4 in an artificial expression system. In situ hybridization analyses indicated that mGluR6 mRNA expression is restricted to the INL of the rat retina (Nakajima et al., 1993; Hartveit et al., 1995). Recently, specific antibodies against mGluR6 produced punctate labeling 
A

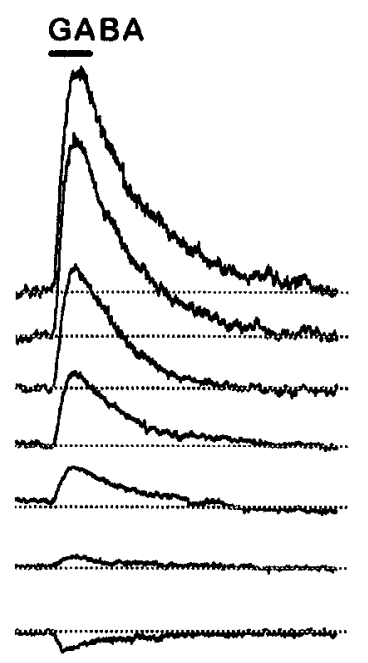

B

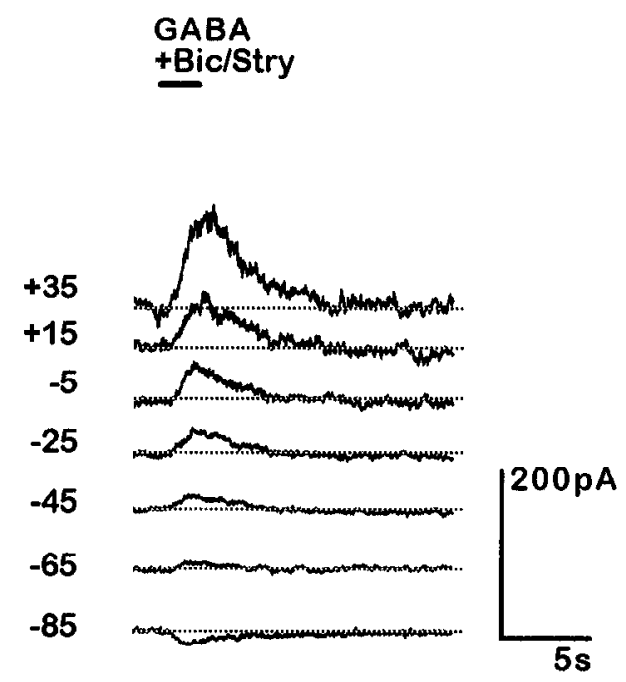

C

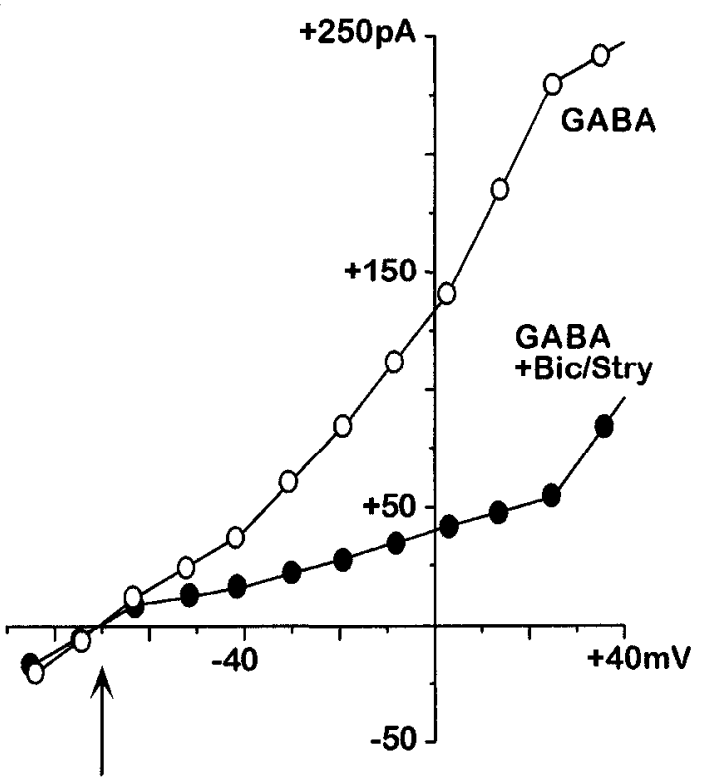

Figure 6. Whole-cell currents recorded from an RB cell during the application of GABA. $A$, GABA induced currents at a range of different holding potentials. The reversal potential was more negative than $-70 \mathrm{mV} . B$, When GABA was co-applied with BIC and STRY (GABA $+B i c / S t r y)$, not all of the GABA-induced current could be blocked, suggesting a BIC-insensitive GABA ${ }_{C}$ component. $C$, Current-voltage curves of the GABA-elicited currents. Both curves have a reversal potential more negative than $-70 \mathrm{mV}$ (arrow) (extracellular solutions, ES; intracellular solution, I3; Nystatin perforated patch).

on the dendritic tips of rat RB cells (Nomura et al., 1994). Immunostaining of $\mathrm{CB}$ cell dendritic tips was not studied by Nomura ct al. (1994); however, when mGluR6 was deleted genetically in mice (knock out), the b wave of the electroretinogram was absent and no ON-responses could be recorded from optic tract terminals, suggesting that the ON-pathway in such animals is nonfunctioning (Masu et al., 1995). The identification of the AP-4 receptor as a metabotropic GluR was supported further by its pharmacological similarity with metabotropic receptors (Tian and Slaughter, 1994; Thoreson et al., 1995; Thoreson and Ulphani, 1995). Therefore the evidence is strong that RB cells and ON-CB cells express the mGluR6 receptor.

In situ hybridization studies of dissociated RB cells indicate that these cells might also express ionotropic GluRs (Hughes et al., 1992; Müller et al., 1992). In the present study, we also observed weak responses to $\mathrm{KA}$ in some $\mathrm{RB}$ cells, which might represent direct effects on the $\mathrm{RB}$ cells. In previous studies of dissociated $\mathrm{RB}$ cells, after washing out the second messenger system of the AP-4 responses (Nawy and Jahr, 1990), we sometimes observed channel openings induced by GLU (Karschin and Wässle, 1990). Therefore it is possible that RB cells in addition to mGluR6 express other GluRs. Whether these receptors are involved in physiological responses is still open to question.

Occasionally in the present study we recorded putative ONbipolar cells, in which the dendrites were cut off during the slicing procedure. This became apparent after the cells were filled with LY. Such truncated cells never showed AP-4 responses, suggesting that the receptors are on the dendrites, as shown by Nomura et al. (1994). In only approximately half of the recorded RB cells did we observe responses to the application of AP-4. There is the possibility that the nonresponding half might express different GluRs; however, there was no evidence for such a dichotomy, and we assume that mechanical damage during the slicing procedure might have broken the finest dendrites of these cells. This was also true for dissociated RB cells (Yamashita and Wässle, 1991b) whenever their dendritic terminals were lost during dissociation.

\section{OFF-bipolar cells of the rat retina}

CB cells with axons terminating in the outer half of the IPL (CB type 1, 2, 3, 4, 5) express KA/AMPA type GluRs. Binding of GLU or KA to this receptor causes the opening of nonspecific cation channels. Because photoreceptors release GLU in the dark (Murakami et al., 1972), such cells are depolarized in darkness: they are UFF-bipolar cells (Murakami et al., 1975).

Molecular cloning has revealed several families of ionotropic GluRs (for revicw, sce Hollmann and Heinemann, 1994). Traditionally these receptors have been classified into three broad subtypes: KA receptors, AMPA receptors, and NMDA receptors. This classification now has been extended, however, and 16 different ionotropic GluRs have been found. Anatomical studies using in situ hybridization techniques and immunocytochemistry (Hughes et al., 1992; Müller et al., 1992; Hamassaki-Britto et al., 1993; Brandstätter et al., 1994; Hartveit et al., 1994; Peng et al., 1995; Watanabe et al., 1994) have shown a differential distribution of the GluR isoforms in the rat INL and IPL. They show that there might be many different subunits, isoforms, and combinations of ionotropic GluR in bipolar cells of the rat retina. In the absence of specific antagonists, these isoforms cannot be distinguished pharmacologically. It is known that different GluRs have different desensitization times (Dudel et al., 1990), and it is possible that the different $\mathrm{CB}$ cells may express kinetically different GluRs. Unfortunatcly application of drugs using puffer pipettes is too slow to obtain kinetically meaningful data. Analysis of light responses may provide additional clues.

\section{Further actions of GLU on rat retinal bipolar cells}

Because bipolar cells release GLU as their transmitter (for review, see Massey, 1990), they may have a high-affinity uptake 
system for GLU. This is supported by the staining of type 5 and 6 CB cells with antibodies against the GLU transporter GLT-1 (Rauen and Kanner, 1994; Euler and Wässle, 1995a). Therefore, it is possible that the GLU responses shown might have been caused by electrogenic GLU uptake at bipolar cell axon terminals. This is probably not so, for the following two reasons. The agonists used in most of the recordings presented here were AP-4 or $\mathrm{KA}$. There is no evidence for the electrogenic transport of AP-4 and KA through GLU transporters in the retina (Eliasof and Werblin, 1993; Danbolt, 1994). We also applied L-tPDC (Rauen et al., 1992), which is transported with high affinity by GLU transporters. Only weak effects were observed in six of seven bipolar cells tested, and these always differed from the responses elicited by AP-4, GLU, or KA. Grant and Dowling (1995) recently described $\mathrm{Cl}^{-}$channels in ON-bipolar cells of the white perch retina that were activated by a GluR with transporter-like pharmacology; however, this channel was not activated by KA or AP-4 and therefore cannot account for the results reported here.

Another possible source of GLU-induced currents are metabotropic GluRs other than mGluR6, the AP-4 receptor. A proposed specific agonist, which binds to mGluR5, is tADA (Favaron et al., 1993; Thoreson and Ulphani, 1995). Five of 10 bipolar cells, all putative ON-bipolars, showed weak effects, which were not investigated in greater detail. This supports the contention that mGluR6 is the major GluR in ON-bipolars.

\section{GABA receptors of rat retina bipolar cells}

In the present study, BIC-sensitive GABA-induced currents were found in almost all bipolar cells, suggesting that all bipolar cells express $\mathrm{GABA}_{\mathrm{A}}$ receptors. Recently we have investigated rat retinae with subunit-specific antibodies against $G_{A B A_{A}}$ receptors (Greferath et al., 1995) and have found multiple $\mathrm{GABA}_{\mathrm{A}}$ receptors in bipolar cells of the rat retina. Hence, several different $\mathrm{GABA}_{\mathrm{A}}$ receptor subtypes might contribute to the BIC-sensitive currents recorded in the present study.

$\mathrm{GABA}_{\mathrm{C}}$ receptors have been described to gate $\mathrm{BIC}$-insensitive $\mathrm{Cl}^{-}$currents in various parts of the vertebrate brain (for review, see Johnston, 1994; Bormann, 1995). In the retina, $\mathrm{GABA}_{\mathrm{C}}$ receptors are present on rat RB cells (Feigenspan et al., 1993; Feigenspan and Bormann, 1994; Pan and Lipton, 1995), on tiger salamander bipolar cells (Dong et al., 1994; Lukasiewicz et al., 1994), and on horizontal cells of the white perch (Qian and Dowling, 1993, 1994). In the present study, we show evidence for $\mathrm{GABA}_{\mathrm{C}}$-receptor expression in $\mathrm{CB}$ cells. $\mathrm{GABA}_{\mathrm{C}}$ receptors are likely to be composed of the recently discovered $\rho 1$ and $\rho 2$ subunits (Cutting et al., 1991, 1992). In situ hybridization of retinal sections revealed the presence of $\rho 1$ and $\rho 2$ transcripts in the INL and in dissociated RB cells of the rat retina (Enz et al., 1995; Pan et al., 1995). Such $\mathrm{GABA}_{C}$ receptors are more sensitive than conventional $\mathrm{GABA}_{\mathrm{A}}$ receptors (Feigenspan and Bormann, 1994); however, more information concerning the precise localization of $\mathrm{GABA}_{\mathrm{A}}$ and $\mathrm{GABA}_{\mathrm{C}}$ reccptors on bipolar cclls is needed before their different roles in visual processing can be determined.

\section{REFERENCES}

Ammermüller J, Kolb $\mathrm{H}$ (1995) The organization of the turtle inner retina. I. ON- and OFF-center pathways. J Comp Neurol 358:1-34.

Attwell D, Mobbs P, Tessier-Lavigne M, Wilson M (1987) Neurotransmitter induced currents in retinal bipolar cells of the axolotl, Ambystoma mexicanum. J Physiol (Lond) 387:125-161.

Ayoub GS, Korenbrot JI, Copenhagen DR (1989) Release of endogenous glutamate from isolated cone photoreceptors of the lizard. Neurosci Res [Suppl] 10:S47-S56.
Barry PH (1994) JPCalc, a software for calculating liquid junction potential corrections in patch-clamp, intracellular, epithelial and bilayer measurements and for correcting junction potential measurements. J Neurosci Methods 51:107-116.

Boos R, Schneider H, Wässle H (1993) Voltage- and transmitter-gated currents of AII-amacrine cells in a slice preparation of the rat retina. J Neurosci 17:2874-2888.

Bormann J, Feigenspan A (1995) GABA $_{C}$ receptors. Trends Neurosci $18: 515-519$

Boycott BB, Kolb H (1973) The connections between bipolar cells and photoreceptors in the retina of the domestic cat. J Comp Neurol 148:91-114.

Boycott BB, Wässle H (1991) Morphological classification of bipolar cells in the macaque monkey retina. Eur J Neurosci 3:1069-1088.

Brandstätter JH, Hartveit E, Sassoè-Pognetto M, Wässle II (1994) Expression of NMDA and high-affinity kainate receptor subunits mRNAs in the adult rat retina. Eur $\mathrm{J}$ Neurosci 6:1100-1112.

Cervetto L, MacNichol Jr EF (1972) Inactivation of horizontal cells in turtle retina by glutamate and aspartate. Science 178:767-768.

Cohen E, Sterling P (1990a) Demonstration of cell types among cone bipolar neurons of cat retina. Philos Trans $\mathbf{R}$ Soc Lond [Biol] 330:305-321.

Cohen E, Sterling P (1990b) Convergence and divergenec of cones onto bipolar cells in the central area of the cat retina. Philos Trans R Soc Lond [Biol] 330:323-328.

Copenhagen D, Jahr CE (1989) Release of endogenous excitatory amino acid from turtle photoreceptors. Nature 341:536-539.

Cutting GR, Curristin S, Zoghbi H, O'Hara BF, Seldin MF, Uhl GR (1992) Identification of a putative $\gamma$-aminobutyric acid (GABA) receptor subunit $\rho 2$ cDNA and colocalization of the genes encoding rho2 (GABRR2) and rho1 (GABRR1) to human chromosome 6q11-q21 and mouse chromosome 4. Genomics 12:801-806.

Cutting GR, Lu L, O'Hara BF, Kasch LM, Montrose-Rafizadeh C, Donovan DM, Shimada S, Antonarakis SE, Guggino WB, Uhl GR, Kazazxian HH (1991) Cloning of the $\gamma$-aminobutyric (GABA) $\rho 1$ cDNA: a GABA receptor subunit highly expressed in the retina. Proc Natl Acad Sci USA 88:2673-2677.

Dacheux RF, Raviola E (1986) The rod pathway in the rabbit retina: a depolarizing bipolar and amacrine cell. J Neurosci 6:331-345.

Danbolt NC (1994) The high affinity uptake system for excitatory amino acids in the brain. Prog Neurobiol 44:377-396.

de la Villa P, Kurahashi T, Kaneko A (1995) L-Glutamate-induced responses and cGMP-activated channels in three subtypes of retinal bipolar cells dissociated from the cat. J Neurosci 15:3571-3582.

Dong C-J, Picaud SA, Werblin FS (1994) GABA transporters and $\mathrm{GABA}_{C}$-like receptors on catfish cone- but not rod-driven horizontal cells. I Neurosci 14:2648-2658

Dudel J, Franke C, Hatt H (1990) Rapid activation, desensitization, and resensitization of synaptic channels of crayfish muscle after glutamate pulses. Biophys J 57:533-545.

Edwards FA, Konnerth A, Sakmann B, Takahashi T (1989) A thin slice preparation for patch clamp recordings from neurons of the mammalian central nervous system. Pflügers Arch 414:600-612.

Eliasof S, Werblin F (1993) Characterization of the glutamate transporter in retinal cones of the tiger salamander. J Neurosci 13:402-411.

Enz R, Brandstätter JH, Hartveit E, Wässle H, Bormann J (1995) Expression of GABA receptor $\rho 1$ and $\rho 2$ subunits in the retina and brain of the rat. Eur J Neurosci 7:1495-1501.

Euler T, Wässle H (1995a) Immunocytochemical identification of cone bipolar cells in the rat retina. J Comp Neurol 361:461-478.

Euler T, Wässle H (1995b) The pharmacology of putative cone bipolar cells in the rat retina. Proceedings of the 23rd Neurobiology Conference, Vol II: Abstr 444.

Famiglietti EV (1981) Functional architecture of cone bipolar cells in mammalian retina. Vision Res 21:1559-1563.

Famiglietti EV, Kolb H (1976) Structural basis for ON- and OFF-center responses in retinal ganglion cells. Science 194:193-195.

Famiglietti EV, Kaneko A, Tachibana M (1977) Neuronal architecture of on and off pathways to ganglion cells in carp retina. Science 198:1267-1269.

Favaron M, Manev RM, Candeo P, Arban R, Gabellini N, Kozikowski AP, Manev H (1993) Trans-azetidine-2,4-dicarboxylic acid activates neuronal metabotropic receptors. NeuroReport 4:967-970. 
Feigenspan A, Bormann J (1994) Differential pharmacology of GABA and $\mathrm{GABA}_{\mathrm{C}}$ receptors on rat retinal bipolar cells. Eur J Pharmacol 288:97-104.

Feigenspan A, Wässle H, Bormann J (1993) Pharmacology of GABA receptor $\mathrm{Cl}^{-}$channels in rat retinal bipolar cells. Nature 361:159-162.

Fenwick EM, Marty A, Neher E (1982) A patch-clamp study of bovine chromaffin cells and of their sensitivity to acctylcholinc. J Physiol (Lond) 331:577-597.

Gillette MA, Dacheux RF (1995) GABA- and glycine-activated currents in the rod bipolar cell of the rabbit retina. J Neurophysiol 74:856-875.

Grant GB, Dowling JE (1995) A glutamate-activated chloride current in cone-driven ON bipolar cells of the white perch retina. J Neurosci 15:3852-3862.

Greferath U, Grünert U, Fritschy JM, Stephenson A, Möhler H, Wässle $H$ (1995) GABA $_{A}$ receptor subunits have differential distributions in the rat retina: in situ hybridization and immunohistochemistry. J Comp Neurol 353:553-571.

Grcferath U, Grünert U, Wässle H (1990) Rod bipolar cells in the mammalian retina show protein kinase C-like immunoreactivity. J Comp Neurol 301:433-442.

Hamassaki-Britto DE, Hermans-Borgmeyer I, Heinemann S, Hughes TE (1993) Expression of glutamate receptor genes in the mammalian retina: the localization of GluR1 through GluR7 mRNAs. J Neurosci 13:1888-1898.

Hamill OP, Marty A, Neher E, Sakmann B, Sigworth FJ (1981) Improved patch-clamp techniques for high-resolution current recording from cells and cell-free membrane patches. Pflügers Arch 391:85-100.

Hartveit E, Brandstätter JH, Enz R, Wässle H (1995) Expression of the mRNA of seven metabotropic glutamate receptors (mGluR1 to 7) in the rat retina. An in situ hybridization study on tissue sections and isolated cells. Eur J Neurosci 7:1472-1483.

Hartveil E, Brandstätter JH, Sassoè-Pognetto M, Laurie DJ, Seeburg PH, Wässle $H$ (1994) Localization and developmental expression of the NMDA receptor subunit NR2A in the mammalian retina. J Comp Neurol 348:570-582.

Hensley SH, Yang X-L, Wu SM (1993) Identification of glutamate receptor subtypes mediating inputs to bipolar cells and ganglion cells in the tiger salamander retina. J Neurophysiol 69:2099-2107.

Hirano AA, MacLeish PR (1991) Glutamate and 2-amino-4-phosphonobutyrate evoke and increase in potassium conductance in retinal bipolar cells. Proc Natl Acad Sci USA 88:805-809.

Hollmann M, Heinemann S (1994) Cloned glutamate receptors. Annu Rev Neurosci 17:31-108.

Hopkins JM, Boycott BB (1995) Synapses between cones and diffuse bipolar cells of a primate retina. J Neurocytol 24:680-694.

Horn R, Marty A (1988) Muscarinic activation of ionic currents measured by a new whole-cell recording method. J Gen Physiol 92:145-159.

Hughes TE, Hermans-Borgmeyer I, Heinemann S (1992) Differential expression of glutamate receptor genes (GluR1-5) in the rat retina. Vis Neurosci 8:49-55.

Ishida AT, Neyton J (1985) Quisqualate and L-glutamate inhibit retinal horizontal-cell responses to kainate. Proc Natl Acad Sci USA 82:1837-1841.

Jcon C-J, Masland RH (1995) A population of wide-field bipolar cells in the rabbit's retina. J Comp Neurol 360:403-412.

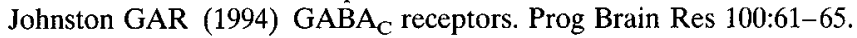

Kaneko A (1979) Physiology of the retina. Annu Rev Neurosci $2: 169-191$.

Karschin A, Wässle H (1990) Voltage- and transmitter-gated currents in isolated rod bipolar cells of rat retina. $J$ Neurophysiol 63:860-876.

Kim HG, Miller RF (1993) Properties of synaptic transmission from photoreceptors to bipolar cells in the mudpuppy retina. J Neurophysiol 69:352-360.

Kolb H (1970) Organization of the outer plexiform layer of the primate retina: electron microscopy of Golgi-impregnated cells. Philos Trans R Soc Lond [Biol] 258:261-283.

Kolb H, Nelson R (1995) The organization of photoreceptor to bipolar synapses in the outer plexiform layer. In: The outer retina (Djamgoz MBA, Archer SN, Vallerga S, eds), pp 273-296. London: Chapman and Hall.

Kolb H, Nelson R, Mariani A (1981) Amacrine cells, bipolar cells and ganglion cells of the cat retina. Vision Res 21:1081-1114.

Lasansky A (1978) Contacts between receptors and electrophysiologically identified neurones in the retina of the larval tiger salamander. J Physiol (Lond) 285:531-542.
Lukasiewicz PD, Maple BR, Werblin FS (1994) A novel GABA receptor on bipolar cell terminals in the tiger salamander retina. $\mathbf{J}$ Neurosci 14:1202-1212.

Marc RE, Lam DMK (1981) Uptake of aspartate and glutamic acid by photoreceptors in goldfish retina. Proc Natl Acad Sci USA 78: 7185-7189.

Massey SC (1990) Cell types using glutamate as a neurotransmitter in the vertebrate retina. In: Progress in retinal research (Osborne N, Chader G, eds), pp 399-426. Oxford: Pergamon.

Masu M, Iwakabe H, Tagawa Y, Miyoshi T, Yamashita M, Fukuda $Y$, Sasaki H, Hiroi K, Nakamura Y, Shigemoto R, Takada M, Nakamura K, Nakao K, Katsuki M, Nakanishi S (1995) Specific deficit of the ON response in visual transmission by targeted disruption of the mGluR6 gene. Cell 80:757-765.

McGuire BA, Stevens JK, Sterling P (1984) Microcircuitry of bipolar cells in the cat retina. J Neurosci 4:2920-2938.

Mills SL, Massey SC (1992) Morphology of bipolar cells labeled by DAPI in the rabbit retina, J Comp Neurol 321:133-149.

Müller F, Greferath U, Wässle H, Wisden W, Seeburg P (1992) Glutamate receptor expression in the rat retina. Neurosci Lett 138:179-182.

Murakami M, Ohtsu K, Ohtsuka T (1972) Effect of chemicals on receptors and horizontal cells in the retina. J Physiol (Lond) 227:899-913.

Murakami J, Ohtsuka T, Shimazaki H (1975) Effects of aspartate and glutamate on the bipolar cells in the carp retina. Vision Res 15: $456-458$.

Nakajima $Y$, Iwakave $H, \Lambda$ kazawa $C$, Nawa $H$, Shigemoto R, Mizuno N, Nakanishi S (1993) Molecular characterization of a novel retinal metabotropic glutamate receptor mGluR6 with a high agonist selectivity for L-2-amino-4-phosphonobutylrate. J Biol Chem 268:11868-11873.

Nawy S, Copenhagen DR (1987) Multiple classes of glutamate receptor on depolarizing bipolar cells in retina. Nature 325:56-58.

Nawy S, Copenhagen DR (1990) Intracellular cesium separates two glutamate conductances in retinal bipolar cells of goldfish. Vision Res 30:967-972.

Nawy S, Jahr CE (1990) Suppression by glutamate of cGMP-activated conductance in retinal bipolar cells. Nature 346:269-271.

Nawy S, Jahr CE (1991) cGMP-gatcd conductance in retinal bipolar cclls is suppressed by the photoreceptor transmitter. Neuron 7:269-271.

Nelson R, Kolb H (1983) Synaptic patterns and response properties of bipolar and ganglion cells in the cat retina. Vision Res 23:1183-1195.

Nelson R, Kolb H, Famiglietti EV, Gouras P (1976) Neural responses in the rod and cone systems of the cat retina: intracellular records and Procion stains. Invest Ophthalmol 15:946-953.

Nomura A, Shigemoto R, Nakamura Y, Okamoto N, Mizuno N, Nakanishi S (1994) Developmentally regulated postsynaptic localization of a metabotropic glutamate receptor in rat rod bipolar cells. Cell 77:361-369.

Pan Z-H, Lipton SA (1995) Multiple GABA receptor subtypes mediate inhibition of calcium influx at rat retinal bipolar cell terminals. J Neurosci 15:2668-2679.

Pan Z-H, Zhang D, Brideau AD, Zhang X, Lipton SA (1995) A single amino acid in the $\rho$ subunits of rat retinal GABA receptors determines picrotoxinin sensitivity. Invest Ophthalmol Vis Sci 36:ARVO Abstr 1306.

Peng Y-W, Blackstone CD, Huganir RL, Yau K-W (1995) Distribution of glutamate receptor subtypes in the vertebrate retina. Neuroscience 66:483-497.

Polenzani L, Woodward RM, Miledi R (1991) Expression of mammalian $\gamma$-aminobutyric acid receptors with distinct pharmacology in Xenopus oocytes. Proc Natl Acad Sci USA 84:4318-4322.

Pourcho RG, Goebel DJ (1987) A combined Golgi and autoradiographic study of ${ }^{3} \mathrm{H}$-glycine-accumulating cone bipolar cells in the cat retina. J Neurosci 7:1178-1188.

Qian H, Dowling JE (1993) Novel GABA responses from rod driven retinal horizontal cells. Nature 361:162-164.

Qian H, Dowling JE (1994) Pharmacology of novel GABA receptors found on rod horizontal cells of the white perch retina. J Neurosci 14:4299-4307.

Ramón y Cajal S (1893) La rétine des vertébrés. La cellule 9:119-257.

Rauen T, Kanner BI (1994) Localization of the glutamate transporter GLT-1 in rat and macaque monkey retinae. Neurosci Lett 169:137-140.

Rauen T, Jeserich G, Danbolt NC, Kanner BI (1992) Comparative analysis of sodium-dependent L-glutamate transport of synaptosomal and astroglial membrane vesicles from mouse cortex. FEBS Lett 312:15-20. 
Saito T, Kondo H, Toyoda J (1979) Ionic mechanisms of two types of on-center bipolar cells in the carp retina. I. The responses to central illumination. J Gen Physiol 73:73-90.

Saito T, Kondo H, Toyoda J (1981) Ionic mechanisms of two types of on-center bipolar cells in the carp retina. II. The responses to annular illumination. J Gen Physiol 78:569-589.

Saito T, Kujiraoka T, Yonaha T (1983) Connections between photoreceptors and horseradish peroxidase-injected bipolar cells in the carp retina. Vision Res 23:353-362.

Saito T, Kujiraoka T, Yonaha T, Chino Y (1985) Reexamination of photoreceptor-bipolar connectivity patterns in carp retina: HRP-EM and Golgi-EM studies. J Comp Neurol 236:141-160.

Sakai H, Naka K-I (1983) Synaptic organizations involving receptor, horizontal and on- and off-center bipolar cells in the catfish retina. Vision Res 23:339-351.

Schwartz EA (1982) Calcium-independent release of GABA from isolated cells of the toad retina. J Physiol (Lond) 323:211-228.

Shiells RA (1995) Photoreceptor-bipolar cell transmission. In: The outer retina (Djamgozz MBA, Archer SN, Vallerga S, eds), pp 297-324. London: Chapman and Hall.

Shiells RA, Falk G (1990) Glutamate receptors of rod bipolar cells are linked to a cyclic GMP cascade via a G-protein. Proc R Soc Lond [Biol] 242:91-94.

Shiells RA, Falk G (1992a) The glutamate receptor linked cGMP cascase of retinal on-bipolar cells is pertussis and cholera toxin-sensitive. Proc $\mathrm{R}$ Soc Lond [Biol] 247:17-20.

Shiells RA, Falk G (1992b) Properties of the cGMP-activated channel of retinal on-bipolar cells. Proc R Soc Lond [Biol] 247:21-25.

Stell WK, Ishida AT, Lightfoot DO (1977) Structural basis for on- and off-center responses in retinal bipolar cells. Science 198:1269-1271.

Sterling P, Smith RG, Rao R, Vardi N (1995) Functional architecture of mammalian outer retina and bipolar cells. In: The outer retina (Djamgoz MBA, Archer SN, Vallerga S, eds), pp 325-348. London: Chapman and Hall.
Suzuki S, Tachibana M, Kaneko A (1990) Effects of glycine and GABA on isolated bipolar cells of the mouse retina. J Physiol (Lond) 421:645-662.

Tian N, Slaughter MM (1994) Pharmacological similarity between the retinal APB receptor and the family of metabotropic glutamate receptors. J Neurophysiol 71:2258-2268.

Thoreson WB, Ulphani JS (1995) Pharmacology of selective and nonselective metabotropic glutamate receptor agonists at L-AP4-receptors in retinal ON bipolar cells. Brain Res 676:93-102.

Thoreson WB, Velte TJ, Miller RF (1995) Actions of phenylglycine derivatives at L-AP4 receptors in retinal ON bipolar cells. Neuropharmacology 34:27-34

Watanabe M, Mishina M, Inoue Y (1994) Differential distributions of the NMDA receptor channel subunit mRNAs in the mouse retina. Brain Res 634:328-332.

Werblin FS (1978) Transmission along and between rods in the tiger salamander retina. J Physiol (Lond) 280:449-470.

Werblin F (1991) Synaptic connections, receptive fields, and patterns of activity in the tiger salamander retina. A simulation of patterns of activity formed at each cellular level from photoreceptors to ganglion cells (The Friedenwald Lecture). Invest Ophthalmol Vis Sci 32: $459-483$

Wu SMS (1987) Synaptic connections between neurons in living slices of the larval tiger salamander retina. J Neurosci Methods 20:139-149.

Yamashita M, Wässle H (1991a) The reversal potential of GABAinduced currents in rod bipolar cells of the rat retina. Vis Neurosci 6:399-401.

Yamashita M, Wässle H (1991b) Responses of rod bipolar cells isolated from the rat retina to the glutamate agonist 2-amino-4phosphonobutyric acid ( $\mathrm{APB})$. J Neurosci 11:2372-2382.

Yeh HH, Lee MB, Cheun JE (1990) Properties of GABA-activated whole-cell currents in bipolar cells of the rat retina. Vis Neurosci $4: 349-357$. 